\title{
Energy, environmental and economic analysis of electric vapour compression and gas driven absorption heat pumps for single-family houses
}

\author{
Giorgio Villa ${ }^{1, *}$, Rossano Scoccia ${ }^{1}$, Tommaso Toppi ${ }^{1}$ and Marcello Aprile ${ }^{1}$ \\ ${ }^{1}$ Politecnico di Milano, Department of Energy, 20156 Milan, Italy
}

\begin{abstract}
The aim of this paper is to compare energy consumptions, $\mathrm{CO}_{2}$ emissions, and operative costs of condensing boilers, electric vapour compression heat pumps and gas driven absorption heat pumps to provide space heating and domestic hot water. The analysis is performed for $140 \mathrm{~m}^{2}$ single-family houses in five different Italian cities whose envelope features depend on the location. For each location, two different envelope conditions are considered. The first one is a non-insulated building, while the second one is the same building, but an external thermal insulation is added on vertical walls and roof. To avoid internal renovation, radiators are maintained as emission system. Combined dynamic simulations are performed to appreciate building and system interactions. A 6 second time step is set to evaluate properly interactions and the DHW profile demand. In addition, the GHP dynamic model is a grey box model experimentally validated. The results show that electric vapour compression heat pumps reach the highest non-renewable primary energy savings ( $>32 \%)$ compared to condensing boilers, but their operative costs are higher due to the higher specific cost of electricity in Italy. Gas driven absorption heat pumps achieve a lower consumption reduction than electric heat pumps $(>22 \%)$, but they have also the minimum operative cost among the three technologies.
\end{abstract}

\section{Introduction}

European buildings represent about $40 \%$ of the overall EU28 energy consumption and $36 \%$ of greenhouse gas emissions [1]. Most of these consumptions are accounted for residential buildings, where $80 \%$ of energy is used for space heating $(\mathrm{SH})$ and domestic hot water (DHW) [2]. The largest number of existing buildings were built before 2001, thus they are energy inefficient according to the current Standards [1]. In addition, the deep renovation process with the aim of improving the energy efficiency takes place slowly [1]. A possible alternative to reduce the energy consumptions for space heating and domestic hot water in a faster way is promoting the heating system renovation [3]. In existing buildings, the most popular heating system consists in a condensing or traditional boiler that provides thermal power to the radiator emission system. Moreover, the boiler provides domestic hot water without the need of an additional water storage. The less impacting renovation for occupied

\footnotetext{
*Giorgio Villa : giorgio.villa@polimi.it
} 
buildings is the replacement of the boiler with a more efficient heat generator, such as heat pumps, maintaining radiators as emission system. The most popular heat pump is the electric vapour compression one (EHP). An additional valid alternative to boilers is the gas driven absorption heat pump (GHP) because it provides high supply water temperatures in an efficient way [3]. Furthermore, for countries with a capillary gas distribution infrastructure, the gas driven heat pump provides the possibility to use renewable energy avoiding a load shift from natural gas to electricity, as it would be required installing electric vapour compression heat pumps. Nevertheless, both GHP and EHP are not able to produce domestic hot water instantaneously as boilers, thus a water storage is required. The aim of this paper is to compare the non-renewable primary energy consumptions, $\mathrm{CO}_{2}$ emissions, and operative costs of condensing boilers, electric vapour compression heat pumps and gas driven absorption heat pumps to provide space heating and domestic hot water. The comparison is performed for heating appliances installed in single family-houses that represent $66 \%$ of the residential building in EU28, in terms of floor area. The analysis considers five different climates referred to five Italian cities (Sondrio, Como, Milano, Roma, and Palermo). For each location, two different types of building envelopes are considered. The first one is a noninsulated single-family house built before 1980, while the second one is the same building, but an external thermal insulation is added on vertical walls and roof. To calculate the energy consumptions, dynamic simulations are performed using the software Trnsys 18 that has been extended with an experimentally validated grey box model of the GHP. An additional improvement, compared to previous works [3] [4], is the use of combined simulations of building and system to appreciate the interaction between them.

\section{Building modelling}

The Italian territory can be divided in six different climatic zones based on the degree-days. For each climatic zone, different building envelope features are considered as suggested in [5]. To achieve results as comparable as possible, the envelope thermal features are different for each climatic zone, while geometry and internal loads/gains are the same for each case.

\subsection{Climate data}

Five different climates associated to five Italian cities are considered (Sondrio, Como, Milano, Roma, and Palermo). The outdoor air temperatures of these locations are comparable with many other European cities, such as the ones of Munich and Paris. The weather files are provided by the CTI (Comitato Termotecnico Italiano). In addition, for each location, the outdoor design temperature and the heating season are shown in Table 1.

Table 1. Heating seasons and outdoor design temperatures

\begin{tabular}{|c|c|c|c|}
\hline Location & $\begin{array}{c}\text { Design } \\
\text { temperature } \\
{ }^{\circ} \mathrm{C}\end{array}$ & $\begin{array}{c}\text { Start heating } \\
\text { season } \\
-\end{array}$ & $\begin{array}{c}\text { End heating } \\
\text { season } \\
-\end{array}$ \\
\hline Sondrio & -10 & $15^{\text {th }}$ October & $15^{\text {th }}$ April \\
\hline Como & -7 & $15^{\text {th }}$ October & $15^{\text {th }}$ April \\
\hline Milan & -5 & $15^{\text {th }}$ October & $15^{\text {th }}$ April \\
\hline Rome & 0 & $1^{\text {st }}$ November & $15^{\text {th }}$ April \\
\hline Palermo & 5 & $1^{\text {st }}$ December & $31^{\text {st }}$ March \\
\hline
\end{tabular}




\subsection{Building description}

The majority of the Italian buildings (74\%) [6] were built before 1980. For this reason, the considered representative building is an old $140 \mathrm{~m}^{2}$ single-family house with two floors (see Figure 1) as described in [7] (Old Building). The "Old Building" has a non-insulated envelope, but double-glazed windows are considered because in the largest number of buildings, old single glazed windows have been replaced with the double-glazed ones in Lombardy (Northern Italian region) [8]. The same assumption is extended to Rome and Palermo. Then, a renovation process for this house is assumed. It consists in adding a thermal insulation on vertical walls and roof and installing low thermal transmittance windows (Renovated Building). The basement remains unchanged to avoid internal renovation in occupied buildings. Therefore, for each location, two different building envelopes are considered. The envelope thermal transmittances are different for each climatic zone. Sondrio, Como, and Milan are in the same climatic zone, called zone E, while Rome and Palermo are in two different climatic zones called D and B respectively. So, the houses located in Sondrio, Como, and Milan have the same geometry and envelope features, while for Rome and Palermo the same geometry is considered, but different thermal transmittances are considered as shown in Table 2. The envelope thermal transmittances are the same used in the reference [5]. The renovated building case study is assumed to be refurbished in the year 2014, so the thermal transmittance values are not fully in agreement with the limits imposed in Italy today by DM 26/05/2015 [17], but they are a little higher.

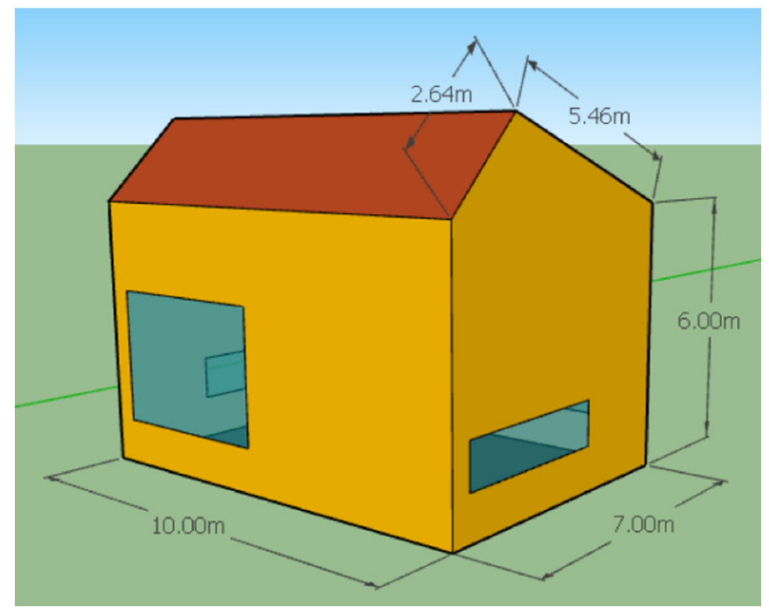

Figure 1: Reference building

Table 2. Envelope thermal transmittances

\begin{tabular}{|c|c|c|c|c|}
\hline Location & Types & & Old building & $\begin{array}{c}\text { Renovated } \\
\text { building }\end{array}$ \\
\hline \multirow{4}{*}{ 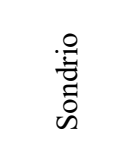 } & Vertical walls & \multirow{4}{*}{$\frac{\widehat{d}}{3}$} & 1.36 & 0.35 \\
\hline & Basement & & 1.61 & 1.61 \\
\hline & Roof & & 1.74 & 0.31 \\
\hline & Windows & & 2.74 & 1.20 \\
\hline \multirow{4}{*}{ ¿̊̃ } & Vertical walls & \multirow{4}{*}{$\underset{3}{\stackrel{d}{d}}$} & 1.36 & 0.35 \\
\hline & Basement & & 1.61 & 1.61 \\
\hline & Roof & & 1.74 & 0.31 \\
\hline & Windows & & 2.74 & 1.20 \\
\hline
\end{tabular}




\begin{tabular}{|c|c|c|c|c|}
\hline$\frac{\text { aี }}{\sum^{2}}$ & $\begin{array}{c}\text { Vertical walls } \\
\text { Basement } \\
\text { Roof } \\
\text { Windows }\end{array}$ & $\frac{\substack{\sqrt{N} \\
\frac{E}{3}}}{3}$ & $\begin{array}{l}1.36 \\
1.61 \\
1.74 \\
2.74\end{array}$ & $\begin{array}{l}0.35 \\
1.61 \\
0.31 \\
1.20\end{array}$ \\
\hline $\begin{array}{l}\text { : } \\
\text { \& }\end{array}$ & $\begin{array}{c}\text { Vertical walls } \\
\text { Basement } \\
\text { Roof } \\
\text { Windows } \\
\end{array}$ & $\frac{\substack{4 \\
\frac{1}{3}}}{3}$ & $\begin{array}{l}1.50 \\
1.61 \\
1.74 \\
2.74 \\
\end{array}$ & $\begin{array}{l}0.41 \\
1.61 \\
0.35 \\
1.20\end{array}$ \\
\hline 志 & $\begin{array}{c}\text { Vertical walls } \\
\text { Basement } \\
\text { Roof } \\
\text { Windows }\end{array}$ & $\underbrace{\frac{2}{2}}_{3}$ & $\begin{array}{l}1.76 \\
1.61 \\
1.74 \\
2.74\end{array}$ & $\begin{array}{l}0.60 \\
1.61 \\
0.38 \\
1.20\end{array}$ \\
\hline
\end{tabular}

\subsection{Internal gains and heat set points}

People, equipment, and lightening are internal gains because they provide heat to the indoor air. To consider these gains, an occupation profile of the building and a profile of the equipment and lightening use are shown in Figure 2 and 3 respectively. It is assumed that a single person provides $20 \mathrm{~W}$ as convective gain and $40 \mathrm{~W}$ as radiative gain [7]. The occupation profile shows the number of people in the building for each hour, while the equipment and lightening profile directly indicates the hourly gains. The same profiles are assumed for each day of the year as in [7]. The gains due to occupation and equipment are $9 \mathrm{kWh} /\left(\mathrm{m}^{2} \mathrm{year}\right)$ and $13.4 \mathrm{kWh} /\left(\mathrm{m}^{2}\right.$ year) respectively. The heat set point is $20^{\circ} \mathrm{C}$ during the day (between 6:00 a.m. and 10:00 p.m.) and $16^{\circ} \mathrm{C}$ during the remaining hours.

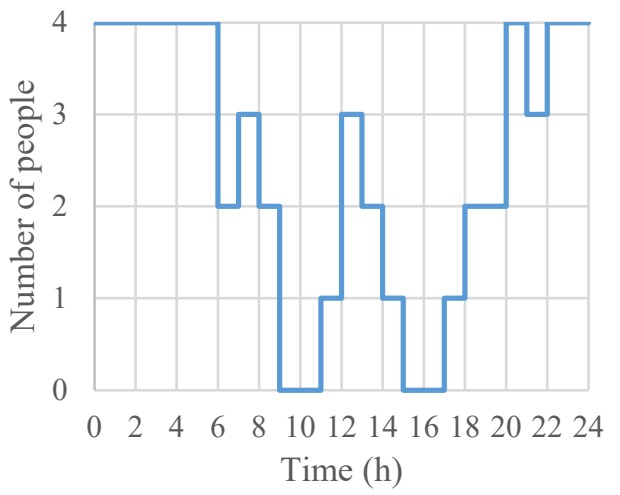

Figure 2. Occupation profile

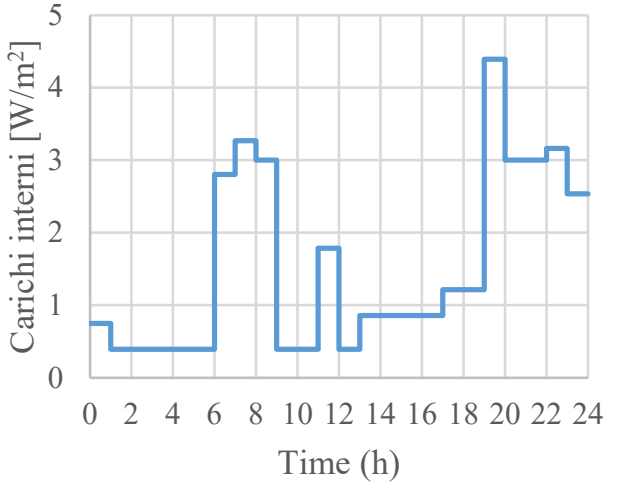

Figure 3. Equipment and lightening gains

\subsection{Domestic hot water}

The dairy tapping profile cycle used is the profile "L" of the European Standard [9]. The choice of the tapping cycle " $\mathrm{L}$ " is based on the number of inhabitants, in this case four. The Standard indicates for each tapping: the typology, the starting hour and the energy contained in the water, in accordance with the typology. The dairy hot water consumption is equivalent to 200 litres at $60{ }^{\circ} \mathrm{C}$. The inlet water temperature is $10^{\circ} \mathrm{C}$ and the energy demand is 11.7 $\mathrm{kWh}$ per day [9]. 


\section{System modelling}

In this section, the design process of the systems, control systems, and dynamic models of boiler, electric vapour compression heat pump, and gas driven absorption heat pump are described. For the other components of the systems, such as radiators and hydraulic pumps, the mathematical models provided by Trnsys 18 [10] [11] are used.

\subsection{System layout and sizing criteria}

Two different system layouts are considered for boilers and heat pumps because they provide useful effects in a different way. In fact, boilers heat up water cooling down the exhaust gases throughout an air-water heat exchanger, while heat pumps provide the useful effect using efficient thermodynamic cycles. It means that the heat pumps switch on phase last few minutes. For this reason, heat pumps are not able to provide instantaneous domestic hot water as boilers. Thus, the heat pumps use a system layout as the one shown in Figure 4, while boilers do not need the water storage. The three-way valve V1 (see Figure 4) gives the possibility to stop the space heating supply to refill the 120 litres water storage, while the three-way valve V5 avoids that a too high water temperature reaches the final user. For both layouts, the design process begins with the calculation of the maximum steady-state heat load of the building and the choice of the emission system capacity. In a real case, if the proposed measures were used, the design procedure would not be needed because the emission system design would have been done before, during the building design. To perform the dynamic simulations, it is assumed that the capacity of the radiators is higher than the steady-state heating load to reduce the heating-up period when the indoor ambient air set-point temperature is switched from $16^{\circ} \mathrm{C}$ to $20^{\circ} \mathrm{C}$, as suggested by the EN 12831-3:2017. In this paper, the capacity of the emission system is assumed $15 \%$ higher than the steady-state heat load. Moreover, to define the mass flow rate, the design supply water temperature has been set equal to $65^{\circ} \mathrm{C}$ and the $\Delta \mathrm{T}$ between supply and return water temperatures at design condition has been set equal to $10^{\circ} \mathrm{C}$. The features of commercial radiators [12] has been used to calculate the number of elements of radiators. The water storage for the heat pumps layout is a 120 litres storage in Class $\mathrm{C}$ in accordance with the Eco-design Directive No $812 / 2013$. The chosen volume is a trade-off between the space occupied by the storage and the DHW taps that the storage is able to fulfil without refiling. Then, to set the capacity of the heat appliances, the following criteria have been used:

- Condensing boiler (CB): the layout system that uses the boiler as heat generator does not have the water storage, so the boiler has to be able to fulfil the domestic hot water demand in an instantaneous way. For each case, the boiler capacity is set to $25 \mathrm{~kW}\left(80^{\circ} \mathrm{C} / 60^{\circ} \mathrm{C}\right)$ because the capacity required to fulfil the domestic hot water demand is higher than all the considered building heat loads.

- Gas driven absorption heat pump (GHP): the GHP capacity has to be the maximum between the steady-state heat load and the capacity needed to fulfil the DHW demand, with a 120 litres water storage. For the "Old Building", the system layout in Figure 4 gives the possibility to set the capacity of the GHP equal to the maximum steady-state heat load. In case of "Renovated Buildings", with low heat loads, the capacity required to fulfil the DHW demand is higher than the one of the space heating. In any case, the supply water temperature and the outdoor temperature influence the performances of the air-water GHP. It means that for each location and building a different capacity is required, as shown in Table 3 . The maximum supply water temperature is $65^{\circ} \mathrm{C}$.

- Electric vapour compression heat pump: (EHP): the design criteria is the same of the GHPs, but EHPs used in this sector are usually not able to achieve supply water temperatures higher than $60^{\circ} \mathrm{C}$. To obtain comparable results, the capacity of the EHP is set equal to the capacity 
of the GHP, evaluated with $60^{\circ} \mathrm{C}$ as supply water temperature, as shown in Table 3 . In addition, EHPs used in this sector are not able to provide high $\Delta \mathrm{T}$ (difference between supply water temperature and return water temperature) as boilers and GHPs. For this reason, the original mass flow rate, calculated during the emission system design, is increased to obtain a $\Delta \mathrm{T}=5^{\circ} \mathrm{C}$ at design conditions.

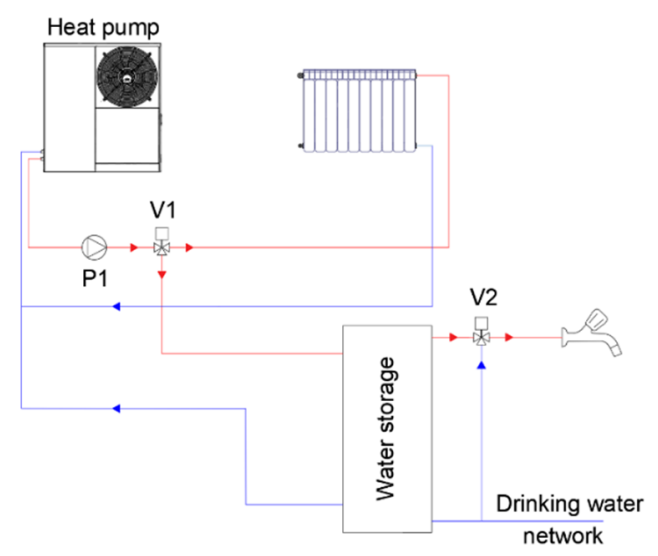

Figure 4. System layout

Table 3. Heat pumps capacity at specific outdoor air temperatures (A) and supply water temperatures (W)

\begin{tabular}{lcccc}
\hline \multicolumn{1}{c}{ Location } & \multicolumn{2}{c}{ Old Building } & \multicolumn{2}{c}{ Renovated Building } \\
\multicolumn{1}{c}{} & GHP & EHP & GHP & EHP \\
- & $\mathrm{kW}$ & $\mathrm{kW}$ & $\mathrm{kW}$ & $\mathrm{kW}$ \\
\hline Sondrio & $17(\mathrm{~A}-10 / \mathrm{W} 65)$ & $17.1(\mathrm{~A}-10 / \mathrm{W} 60)$ & $8(\mathrm{~A}-10 / \mathrm{W} 65)$ & $8.4(\mathrm{~A}-10 / \mathrm{W} 60)$ \\
Como & $15(\mathrm{~A}-7 / \mathrm{W} 65)$ & $15.6(\mathrm{~A}-7 / \mathrm{W} 60)$ & $8(\mathrm{~A}-7 / \mathrm{W} 65)$ & $8.4(\mathrm{~A}-7 / \mathrm{W} 60)$ \\
Milan & $14(\mathrm{~A}-5 / \mathrm{W} 65)$ & $14.7(\mathrm{~A}-5 / \mathrm{W} 60)$ & $8(\mathrm{~A}-5 / \mathrm{W} 65)$ & $8.4(\mathrm{~A}-5 / \mathrm{W} 60)$ \\
Rome & $12(\mathrm{~A} 0 / \mathrm{W} 65)$ & $12.6(\mathrm{~A} 0 / \mathrm{W} 60)$ & $8(\mathrm{~A} 0 / \mathrm{W} 65)$ & $8.4(\mathrm{~A} 0 / \mathrm{W} 60)$ \\
Palermo & $10(\mathrm{~A} 5 / \mathrm{W} 65)$ & $10.6(\mathrm{~A} 5 / \mathrm{W} 60)$ & $8(\mathrm{~A} \mathrm{5/W65)}$ & $8.4(\mathrm{~A} \mathrm{5/W60)}$ \\
\hline
\end{tabular}

\subsection{Control system}

The control strategy depends on the system layout (i.e. boiler system and heat pump system). In the boiler system layout, without the water storage, the boiler provides instantaneous DHW interrupting the supply of thermal power to radiators during the heating season. The space heating control system is a differential controller that maintains the indoor ambient temperature between $20^{\circ} \mathrm{C}$ and $21^{\circ} \mathrm{C}$ between 6:00 a.m. and 10:00 p.m. and between $16^{\circ} \mathrm{C}$ and $17^{\circ} \mathrm{C}$ during the remaining part of the day. The climatic curves used to set the supply temperature to the radiators in function of the outdoor temperature are shown in Figure 5 and 6. To obtain comparable results, the same level of thermal comfort has to be achieved. Therefore, the climatic curves have been tuned in order to guarantee the indoor air set-point of $20^{\circ} \mathrm{C}$ for $85 \%$ of the January hours. As expected, the buildings in the coldest city, Sondrio, have the highest reduction of the supply water temperatures because the heating system is designed to supply the nominal thermal power at $-10^{\circ} \mathrm{C}$ (outdoor temperature). On the other hand, in the warmest city, Palermo, the design outdoor temperature is $5^{\circ} \mathrm{C}$ and the system is designed to have $65^{\circ} \mathrm{C}$ as supply water temperature in that condition. The only exception to this reasoning is the case in Como. The reason why is that the weather date we used shows several days in January where the outdoor temperatures are relatively low during the 
mornings. This leads to higher supply water temperatures than Milan to guarantee the daily indoor air set-point temperature. This behaviour is mitigated in the "Renovated Building" Como case thanks to the higher envelope thermal insulation.

In the heat pump system layout, shown in Figure 4, the space heating is controlled as described before, while DHW is provided by the water storage. In this way, the space heating interruptions are reduced. However, heat pumps have a lower nominal capacity than boilers, so using the same climatic curves lower comfort levels would be achieved. To reach the same comfort level $(85 \%)$, the heat pump starting time is anticipated. The water storage is maintained between $52^{\circ} \mathrm{C}$ and $58^{\circ} \mathrm{C}$ for the "Old building" and between $55^{\circ} \mathrm{C}$ and $58^{\circ} \mathrm{C}$ for the "Renovated building". This difference is given by the fact that a 120 litres storage maintained between $52^{\circ} \mathrm{C}$ and $58^{\circ} \mathrm{C}$ coupled with an $8 \mathrm{~kW}$ heat pump is not able to completely fulfil the DHW demand. In addition, the volume of the storage is lower than the daily water use $\left(200\right.$ litres at $\left.60^{\circ} \mathrm{C}\right)$, thus it needs to be refilled more than once during a single day. To furtherly reduce the space heating interruptions, the storage is refilled 30 minutes before the space heating starting time.

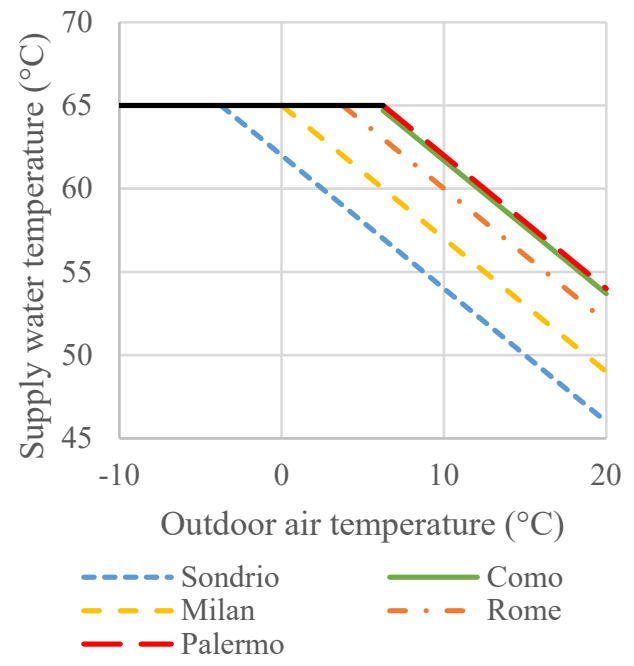

Figure 5. Climatic curves - Old Buildings

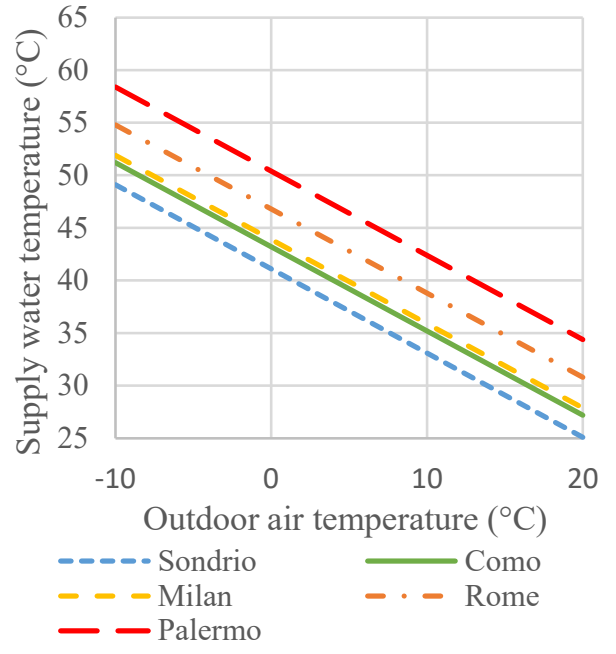

Figure 6. Climatic curves - Renovated Buildings

\subsection{Condensing boiler model}

The mathematical model of the condensing boiler is based on the European Standard [13]. In particular, the "boiling cycling method" is used. Many aspects affect the boiler efficiency, such as the type of generator, control system, load factor, return water temperature, and so on. In this case, an efficient modulating condensing boiler has been selected. As shown in Figure 7, its efficiency mainly depends on the return water temperature and on the load factor (LF), which is the ratio between the output thermal power and the nominal capacity of the boiler. The curves in Figure 7 show that a low return water temperature promotes the flue gases condensation, improving the boiler efficiency. In addition, the load factor significantly affects the boiler efficiency because the flue gas heat exchanger is more efficient with low mass flow rates [3]. 


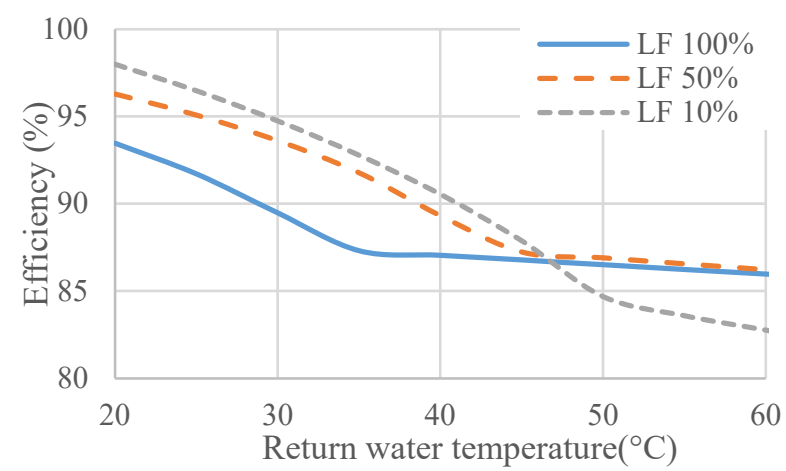

Figure 7. Condensing boiler efficiency

\subsection{Gas driven absorption heat pump model}

The GHP model is based on an accurate grey box model, described in [14]. This model considers a $40 \mathrm{~kW}$ brine-to-water commercial unit and divides the heat pump model in three main sub models: a grey-box model of the combustion chamber, a lumped parameter model of the flue gas heat exchanger, and an entropy-based model of the ammonia water Generator Absorber heat eXchange (GAX) cycle [14]. The GAX cycle gives the possibility to recover part of the heat output of the absorber to pre-heat the rich solution before it is sent to the generator. This feature provides the possibility to obtain high seasonal performances with a relative limited increase of complexity of the cycle. The mathematical model calculates the output water temperature, the useful heat provided to the water $\left(\mathrm{Q}_{\mathrm{hw}}\right)$ and the natural gas consumption $\left(Q_{\text {gas }}\right)$. The inputs are the inlet water temperature, water mass flow rate, outdoor air temperature and the water temperature set point. This model is a scalable model, and it can be adapted to low-capacity heat pumps as described by the simplified model in [15]. Figure 8 shows how the model in [15] works. The combustion chamber model (CC) is a simple integral model of the gas furnace and generator that calculates the heat input to the generator $\left(Q_{g}\right)$, the mass flow rate on dry gas basis and the temperature of the gases leaving the chamber. To calculate them, the gas input $\left(Q_{\text {gas }}\right)$, the combustion efficiency $\left(\eta_{\mathrm{cmb}}\right)$ and the thermal efficiency $\left(\eta_{\mathrm{th}}\right)$ are required. The flue gas heat exchanger (FHX) calculates the heat recovered from the flue gas $\left(\mathrm{Q}_{\mathrm{fhx}}\right)$ to heat up the water. The absorption cycle model (ABS) calculates the heat provided to the water by absorber and condenser $\left(Q_{a+c}\right)$, the outlet water temperature $\left(\mathrm{T}_{\mathrm{hwo}}\right)$ and the coefficient of performance (COP) of the absorption cycle using the entropy balance of the cycle. The P-T-x diagram in Figure 9 shows a qualitative representation of the cycle. It is specific to the heat input $\left(Q_{g}\right)$ and $\alpha$ is the ratio between the heat leaving the absorber $\left(Q_{a}\right)$ and the input heat at the generator $\left(Q_{g}\right)$. Then, the heat input at the evaporator divided by the heat input at the generator is (COP-1) and performing the energy balance of the cycle, neglecting the work input at the solution pump and heat losses, the heat leaving the condenser is obtained (COP- $\alpha$ ). In addition, the diagram shows the heat recovered, in a component of the cycle called SCA, to pre-heat the rich solution. The model needs a series of predefined parameters and experimentally identified parameters to calculate the internal temperatures as described in [15], thus a set of experimental data similar to the one in [14] have been measured on a low capacity GHP prototype. 


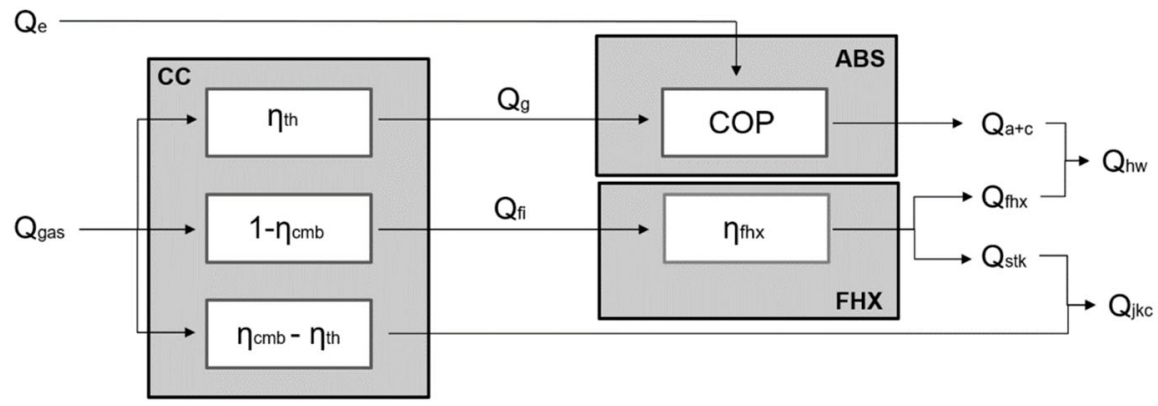

Figure 8. GHP thermodynamic process

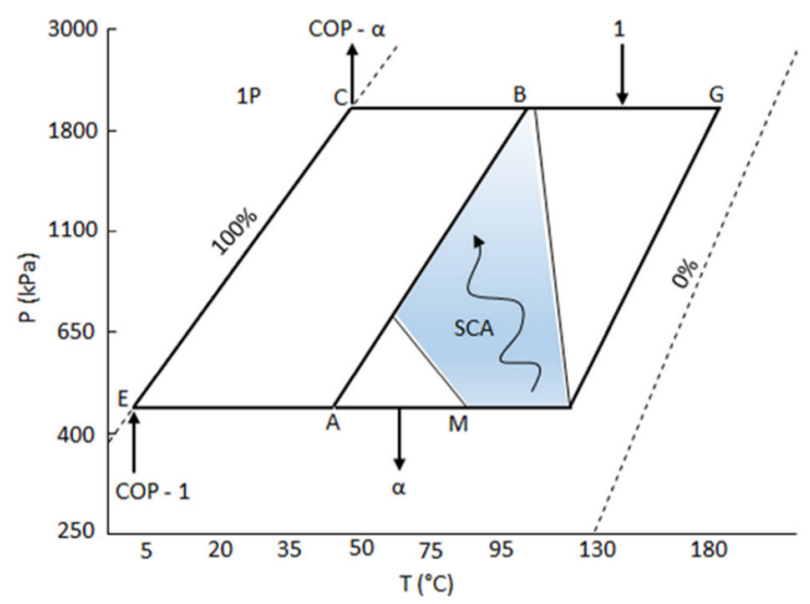

Figure 9. Absorption cycle in a P-T-x diagram

Moreover, to obtain an air-water heat pump model, a hydronic loop with brine as heat carrier fluid has been added. In this way, the brine is cooled down in the evaporator of the absorption cycle and heated up in an air-water heat exchanger. The performances of the GHP are shown in Figure 10 and 11. The first one presents the Gas Utilization Efficiency (GUE), calculated as the ratio between the delivered heat and the gas input in terms of gross calorific value, as function of the return water temperature and the outdoor air temperature. A low return water temperature provides a high GUE because both the absorption cycle performances and the flue-gas heat recovery are increased. In contrast, a low outdoor air temperature $\left(T_{\text {air }}\right)$ reduces the evaporation temperature and pressure leading to a low GUE. The second one shows the trend of the GUE as function of the outdoor air temperature $\left(T_{\text {air }}\right)$ and the gas input ratio (GIR) that is defined as the ratio between the actual natural gas input and the nominal gas input. The GUE decreases at the decrease of the gas input ratio and this reduction is more important for low $T_{\text {air }}$ In addition, the heat input at the evaporator could be zero at very low gas input fractions. In this case, the GHP works as a gas boiler [14]. 


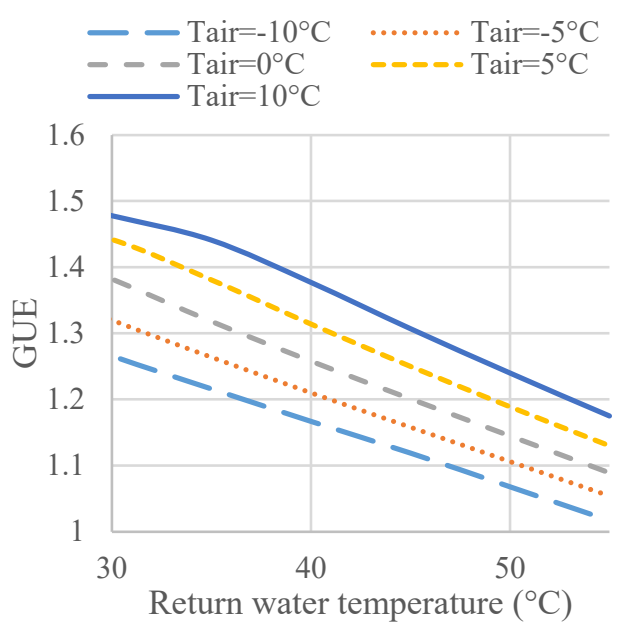

Figure 10. GUE for nominal gas input

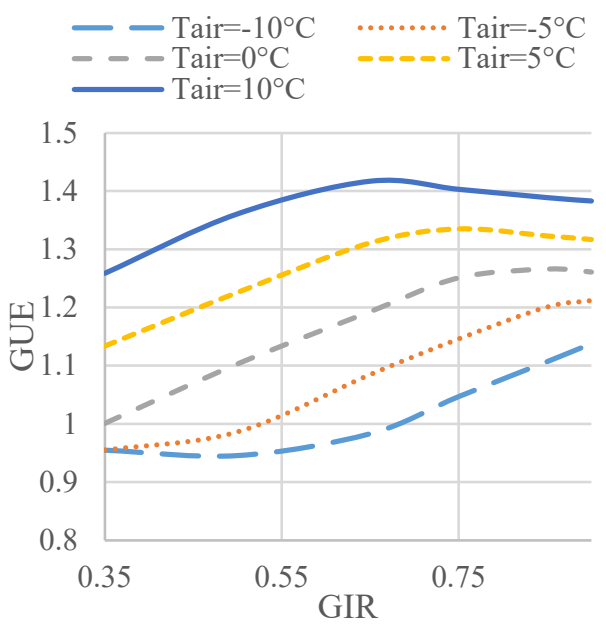

Figure 11. GUE for variable gas input

\subsection{Electric vapour compression heat pump model}

The EHP model is based on a commercial heat pump performance map [16]. The performances depend on the return water temperature $\left(T_{i n}\right)$, mass flow rate $(\dot{m})$, outdoor air temperature $\left(T_{\text {air }}\right)$, and set-point temperature $\left(T_{\text {set }}\right)$. The outputs of the model are the electricity consumption $\left(\dot{W}_{e l}\right)$ and the outlet water temperature $\left(T_{\text {out }}\right)$. To calculate them, the model compares $\dot{Q}_{\text {need }}$ calculated by Equation 1 and $\dot{Q}_{F L}$, which is the maximum thermal power provided by the EHP at the same $T_{\text {air }}$ and $T_{\text {in }}$, indicated by the performance map. If $\dot{Q}_{\text {need }}$ is equal to or lower than $\dot{Q}_{F L}, T_{\text {out }}$ is set equal to $T_{\text {set }}$ as shown by Equation 2, otherwise the heat output $\left(\dot{Q}_{\text {out }}\right)$ is set equal to $\dot{Q}_{F L}$ and the outlet temperature is calculated as shown by Equation 3. Then, the coefficient of performance (COP) is selected in the performance map, as function of $T_{\text {air }}, T_{i n}$ and the load factor (LF) defined as the ratio between the actual delivered thermal power and $\dot{Q}_{F L}$. To conclude, $W_{e l}$ is calculated as the ratio between $\dot{Q}_{\text {out }}$ and COP.

$$
\begin{gathered}
\dot{Q}_{\text {need }}=\dot{m} \cdot c_{p} \cdot\left(\mathrm{T}_{\text {set }}-T_{\text {in }}\right) \\
\dot{Q}_{\text {need }} \leq \dot{Q}_{F L} \rightarrow\left\{\begin{array}{l}
\dot{Q}_{\text {out }}=\dot{Q}_{\text {need }} \\
T_{\text {out }}=T_{\text {set }}
\end{array}\right. \\
\dot{Q}_{\text {need }}>\dot{Q}_{F L} \rightarrow\left\{\begin{array}{l}
\dot{Q}_{\text {out }}=\dot{Q}_{F L} \\
T_{\text {out }}=T_{\text {in }}+\frac{\dot{Q}_{\text {out }}}{\dot{m} \cdot c_{p}}<T_{\text {set }}
\end{array}\right.
\end{gathered}
$$

In Figure 12 is shown the COP of the EHP at nominal capacity for different output water temperatures and outdoor air temperatures. It is clear that the COP decreases at the increase of the output temperature and at the decrease of the outdoor air temperature. In additon, COP is more influenced by output water temperature at high outdoor temperatures. Then, the impact of the load factor on the COP is quite absent, in fact, the COP slightly increase at the decrease of LF. 


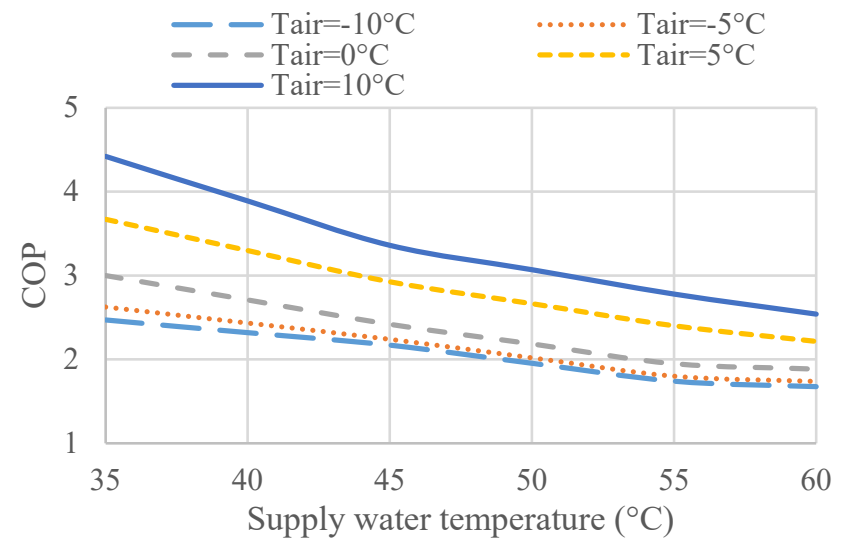

Figure 12. COP nominal capacity

\section{Results}

In this section, heating needs, non-renewable primary energy consumptions, $\mathrm{CO}_{2}$ emissions, and operative costs are shown. The dynamic simulations are performed with a 6 second timestep to properly evaluate the DHW demand and the interaction between buildings and systems.

\subsection{Heating need}

The yearly space heating demands are shown in Table 4 for each location and envelope condition. Moreover, the DHW demand is $30.5 \mathrm{kWh} / \mathrm{m}^{2} /$ year. It is calculated multiplying the daily DHW demand, described in Section 2.4, by the number of days.

Table 4. Annual heating needs

\begin{tabular}{lcc}
\hline $\begin{array}{c}\text { Location } \\
-\end{array}$ & $\begin{array}{c}\text { Old Building } \\
\mathrm{kWh} / \mathrm{m}^{2} / \text { year }\end{array}$ & $\begin{array}{c}\text { Renovated Building } \\
\mathrm{kWh} / \mathrm{m}^{2} / \text { year }\end{array}$ \\
\hline Sondrio & 240 & 100 \\
Como & 229 & 96 \\
Milan & 197 & 87 \\
Rome & 133 & 64 \\
Palermo & 82 & 57 \\
\hline
\end{tabular}

\subsection{Non-renewable primary energy consumption}

Non-renewable primary energy consumptions of the considered systems are shown in Figure 13 and 14 for "Old Building" and "Renovated Building" respectively. The calculation of the non-renewable primary energy consumption depends on the coefficients used for the conversion of electricity and natural gas into non-renewable primary energy. In this case, values equal to $1.95 \mathrm{kWh}_{\mathrm{nPE}} / \mathrm{kWh}_{\mathrm{el}}$ and $1.05 \mathrm{kWh}_{\mathrm{nPE}} / \mathrm{kWh}_{\mathrm{ng}}$ are used for electricity and natural gas respectively, as suggested by the Italian law [17]. The condensing boiler primary energy consumptions are driven by natural gas. In fact, the circulation hydraulic pump is the only electricity consumption, other electricity consumptions are considered negligible. On the contrary, the EHP uses only electricity, while its natural gas consumption is zero. Then, the GHP mainly consumes natural gas, but it has also a not negligible consumption of 
electricity, caused by the circulation hydraulic pump, rich solution hydraulic pump, brine hydraulic pump, and secondary loop fan.

To compare the results, the $\mathrm{CB}$ consumptions are considered as reference:

- For the "Old Building" (see Figure 13), CB is the appliance that consumes the higher amount of non-renewable primary energy in every case. In contrast, EHP gives the possibility to obtain a reduction of non-renewable primary energy consumption between $32 \%$ and $46 \%$, while GHP is able to achieve savings between $22 \%$ and $28 \%$.

- For the "Renovated Building" (see Figure 14), the energy consumptions are strongly reduced compared to the previous ones due to the envelope insulation. In fact, an insulated envelope provides a heating need reduction, as shown in Table 4, and an increase of the appliance's performances, due to the supply water temperature reduction as shown by the climatic curves in Figure 5 and 6. Even in this case, the CB is the less efficient technology. On the other hand, EHP achieves high performances and reaches non-renewable primary energy savings between $44 \%$ and $55 \%$ compared to CB. GHP is more efficient than the condensing boiler, but it does not reach savings as high as EHP. In fact, GHP energy savings are between $28 \%$ and $32 \%$.

Moreover, results show that the non-renewable primary energy saving gaps between GHP and EHP are different in Old and Renovated Buildings. In fact, the Old Building differences between the consumptions of EHPs and GHPs are lower than the Renovated Building ones. This difference is caused by the influence of the supply water temperature on the performances. As shown in Figure 10 and 12, the performances of EHPs are more influenced by the supply water temperature than GHPs' ones.

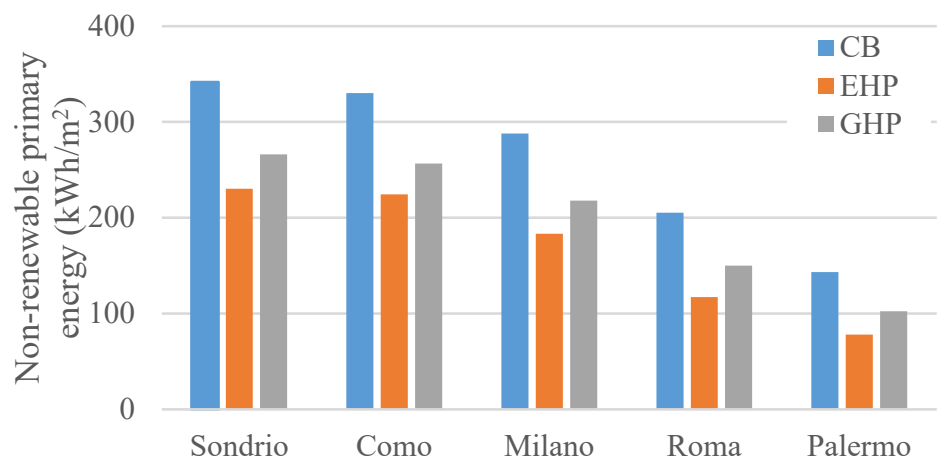

Figure 13. Non-renewable primary energy consumptions (Old Buildings)

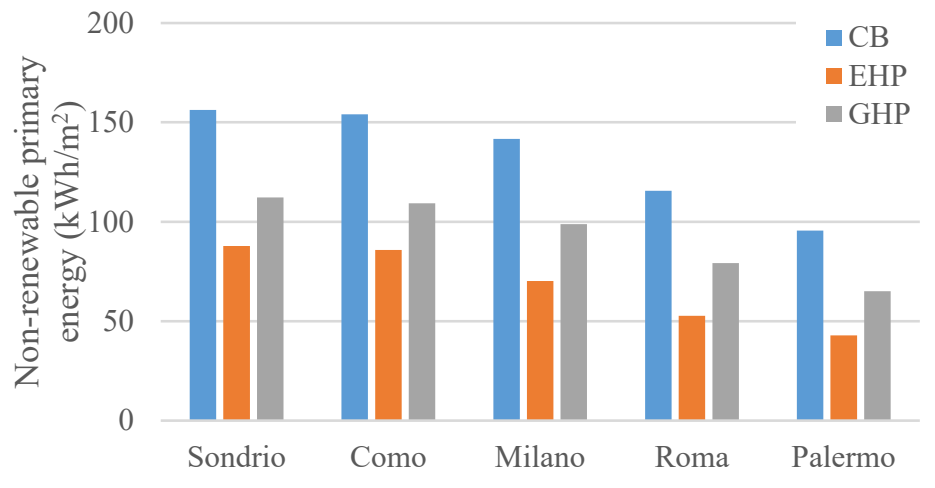

Figure 14. Non-Renewable primary energy consumptions (Renovated Buildings) 


\section{3 $\mathrm{CO}_{2}$ emissions}

The $\mathrm{CO}_{2}$ emissions is an additional important indicator to compare different technologies. To calculate this indicator, an emission intensity for the electricity equal to $233 \mathrm{~g}_{\mathrm{CO} 2} / \mathrm{kWh}$ is used [18]. For natural gas, a value equal to $205 \mathrm{~g}_{\mathrm{CO} 2} / \mathrm{kWh}$ is set [3]. The results are shown in figure 15 and 16 for the different locations and envelope building conditions. In any case, heat pumps reduce the $\mathrm{CO}_{2}$ emissions. The decreasing trend is similar to the one shown for non-renewable primary energy consumptions. In fact, the envelope insulation is an effective measure to reduce energy consumptions and $\mathrm{CO}_{2}$ emissions. Among the considered heat generator technologies, EHP is the one with the lowest emissions followed by GHP, as shown for energy consumptions.

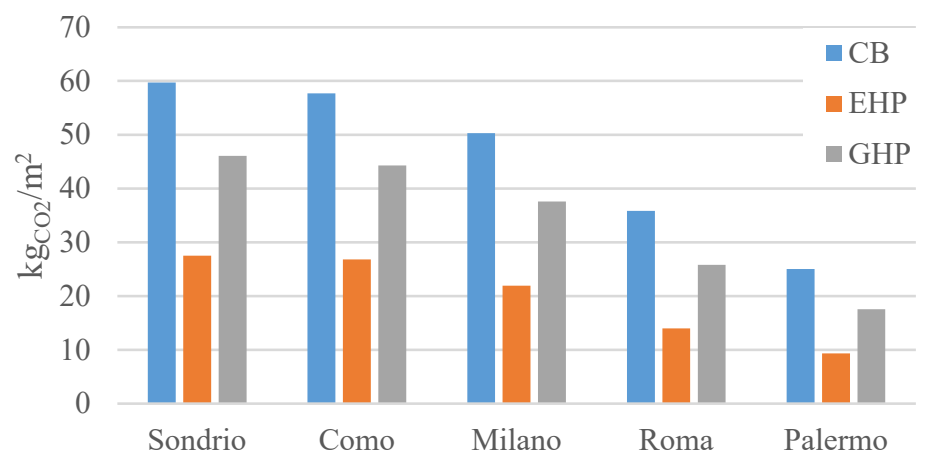

Figure 15. $\mathrm{CO}_{2}$ emissions (Old Buildings)

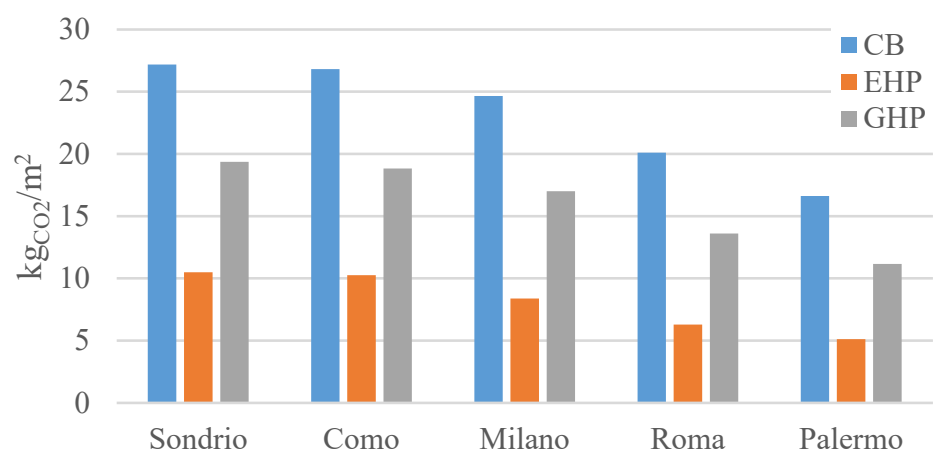

Figure 16. $\mathrm{CO}_{2}$ emissions (Renovated Buildings)

\subsection{Economic analysis}

Heat pumps are more efficient than condensing boilers. However, to achieve high performances, complex thermodynamic cycles are required. It means that the initial cost of heat pumps could be higher than the one of condensing boilers. In addition, the heat pump system layout needs the water storage, not required by the boiler. Therefore, a complete comparison that considers initial cost and operative costs would be needed. However, an objective direct comparison between the initial cost of a well-known technology as the condensing boiler and a relative new technology as low capacity GHPs is not possible. In fact, the availability of low capacity GHP on the market is very limited now. For these reasons, a comparison between operative costs is proposed in this paper. As operative costs are considered the annual costs that the final user has to sustain to buy electricity and natural 
gas. In Italy, the natural gas price is $0.0728 € / \mathrm{kWh}$ [19], while the electricity price is 0.2226 $€ / \mathrm{kWh}[20]$. Considering the CB case as reference, Figures 17 and 18 are described:

- For the "Old Building" (see Figure 17), the minimum annual operative cost is given by GHP. In fact, the reduced consumptions with respect to $\mathrm{CB}$, combined with the low price of natural gas, compared to the electricity one, leads to achieve the lowest operative costs. On the other hand, EHP presents operative costs higher than CB for the climatic zone E (Sondrio, Como, and Milano). It means that, without incentives, the EHPs are not sustainable under the economic point of view for these cities because both operative and initial costs of EHP are higher than the condensing boiler ones. EHPs become competitive for favourable climates as for Rome and Palermo, but its operative costs are still higher than the ones of GHPs.

- For "Renovated Buildings" (see Figure 18), GHP is still the best solution for the climatic conditions of Sondrio, Como, and Milan. However, EHPs become convenient for Rome and Palermo because the high-energy savings exceed the higher costs of electricity.

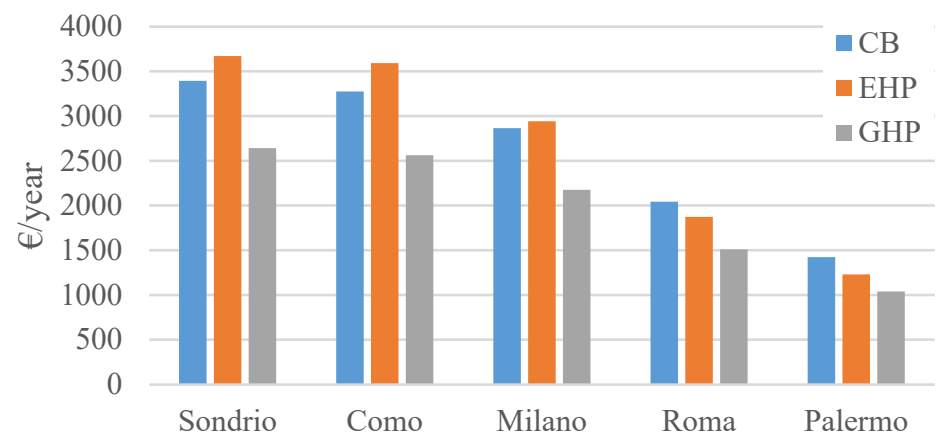

Figure 17. Operative costs (Old Buildings)

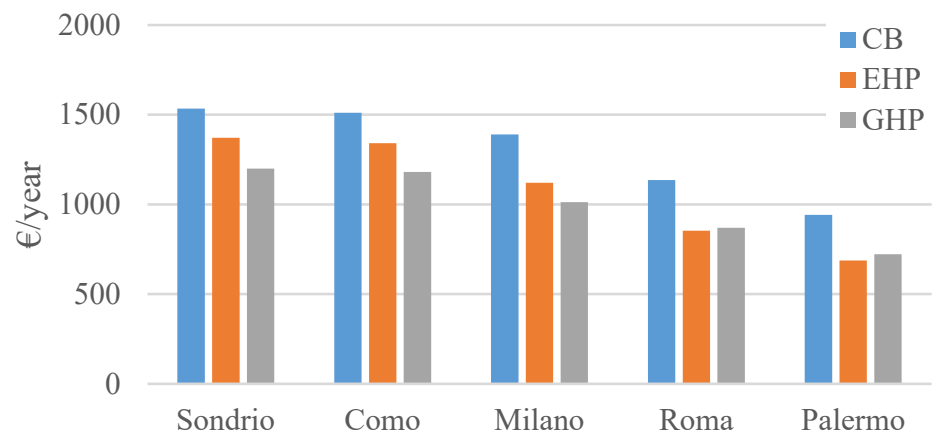

Figure 18. Operative costs (Renovated buildings)

\section{Conclusions}

In this paper, a comparison between non-renewable primary energy consumptions, $\mathrm{CO}_{2}$ emissions, and operative costs of three different technologies is performed throughout dynamic simulations. The analysis considers five different Italian cities (Sondrio, Como, Milan, Rome, and Palermo) and two existing buildings envelope conditions. The first one is a non-insulated single-family house built before 1980 (Old Building). The second one is the 
same house, but a renovation process that consists in vertical walls and roof insulation is assumed (Renovated Building). For both, "Old Building" and "Renovated Building" the envelope thermal transmittances depend on their location. In addition, a radiator emission system is used for every case. The results show that for both non-insulated buildings and insulated buildings, electric vapour compression heat pumps and gas driven absorption heat pumps reduce the non-renewable primary energy consumptions and $\mathrm{CO}_{2}$ emissions compared to condensing boilers. Among them, electric vapour compression heat pumps achieve the highest reduction of non-renewable primary energy consumptions and $\mathrm{CO}_{2}$ emissions for every considered condition. However, a mixture of natural gas and hydrogen could be used as input for absorption heat pumps in the near future. The hydrogen production could be done using renewable energy. It means that, the non-renewable primary energy consumptions of absorption heat pumps may be strongly reduced. Then, an analysis of the operative costs has been performed. The GHP is the technology with the lowest operational costs in almost all the considered cases. It is because GHP is more efficient than the condensing boiler and because the natural gas cost is lower than the electricity one in Italy. Electric vapour compression heat pumps, under the operative cost point of view, are favourable only for insulated buildings in Rome and Palermo. A more detailed economic analysis that considers also initial costs would be required to achieve a complete and objective analysis, but the currently data available does not give the possibility to compare the initial cost of a low capacity GHP prototype with a well-known technology as the condensing boiler. To summarise, both EHP and GHP achieve remarkable non-renewable primary energy savings. EHP seems to be the one that achieve the best energy performances, but the higher specific cost of electricity could limit its diffusion. On the other hand, GHP has a higher not renewable primary energy consumption than EHP, but it has a lower operative cost. In addition, the use of GHP instead of gas boiler avoid the load shift from natural gas grid to the electric grid, as it would be required in the case of a massive EHP installation.

\section{References}

[1] European Commission, A Renovation Wave for Europe-greening our buildings, creating jobs, improving lives, Brussels, (2020).

[2] European Environment Agency, Indicator assesment- Progress on energy efficiency in Europe, (2016).

[3] R. Scoccia, T. Toppi, M. Aprile and M. Motta, J. Build. Engineering, 16, pp. 94105, (2018).

[4] D. Pineau, P. Rivière, P. Stabat, P. Hoang and V. Archambault, Energy and Buildings, 65, pp. 45-54, (2013).

[5] F. Lombardi, M. V. Rocco, S. Locatelli, C. Magni, E. Colombo, L. Belussi and L. Danza, Italian J. of Engineering Science, 63, pp. 349-356, (2019).

[6] ISTAT, Censimento popolazione ISTAT, (2011).

[7] R. Dott, M. Y. Haller, J. Ruschenburg, F. Ochs and J. Bony, IEA SHC Task 44/HPP Annex 38, (2013).

[8] CENED, OPENDATA-DATI CENED+1.2, (2017).

[9] European Committee, EN 130203-2:2015 Gas-fired domestic appliances producing hot water, (2015).

[10] J. W. Thornton, D. E. Bradley, T. P. McDowell, N. J. Blair, M. J. Duffy, N. D. LaHam and A. V. Naik, TESSLibs 17 Component Libraries for the TRNSYS 
Simulation Environment, HVAC Library Mathematical Reference, Madison, Thermal Energy System Specialists, (2014).

[11] S. A. Klein, W. A. Beckman, J. W. Mitchell, J. A. Duffie, N. A. Duffie, T. L. Freeman, J. C. Mitchell, J. E. Braun, B. L. Evans, J. P. Kummer, R. E. Urban, A. Fiksel, J. W. Thornton, N. J. Blair, P. M. Williams, D. E. Bradley, T. P. McDowell, M. Kummert, D. A. Arias, M. J. Duffy and A. M. Weiss, TRNSYS 18 a TRaNsient SYstem Simulation program, Volume 4 Mathematical Reference, Madison, Solar Energy Laboratory and Thermal Energy System Specialists, (2018).

[12] Global Radiatori, Klass Global radiatori, [Online]. Available: http://www.globalradiatori.it/public/Prodotti/klassIT06-05.pdf.

[13] European Standard, UNI EN 15316-4-1 Method for calculation of system energy requirements and system, (2008).

[14] M. Aprile, R. Scoccia, T. Toppi and M. Motta, Appl. Thermal Engineering, 118, pp. 214-223, (2017).

[15] G. Villa, T. Toppi, M. Aprile and M. Motta, ISHPC 2021 Proceedings part2, pp. 21-25, (2021).

[16] Carrier United Technologies, Pompe di Calore Aria-Acqua a ciclo Reversibile/Refrigeratori.

[17] “DM 26/06/2015” Ministero dello sviluppo economico, 2015.

[18] European Environment Agency, Greenhouse gas emission intensity of electricity generation, (2019).

[19] Eurostat, Gas prices for household consumers - bi-annual data.

[20] Eurostat, Electricity prices for household consumer- bi-annual data, (2020). 